\title{
Contents, Vol. 61, Supplement 1, 1992
}

\section{Contents}

Robertson, B.; Halliday, H.L.; Speer, C.P.; Büky, B.

PrefaceValls-i-Soler, A.; Lizaraga, M.; Lopez de Heredia, J.; Roman, L.; Hernáez, E.;

Gastiasoro, E.

Effectiveness of Curosurf for Severe Respiratory Distress Syndrome: A Case-Control Study 21

Herting, E.; Speer, C.P.; Harms, K.; Robertson, B.; Curstedt, T.; Halliday, H.L.; Compagnone, D.; Gefeller, O.; McClure, G.; Reid, M.; Tubman, T.R.J.; Herin, P.; Noack, G.; Kok, J.; Koppe, J.; van Sonderen, L.; Laufkötter, E.; Köhler, W.; Boenisch, H.; Albrecht, K.; Roll, C; Hanssler, L.; Haim, ML; Oetomo, S.B.; Okken, A.; Altfeld, P.C.; Groneck, P.; Kachel, W.; Relier, J.P.; Walti, $\mathrm{H}$.

Factors Influencing Morbidity and Mortality in Infants with Severe Respiratory Distress Syndrome Treated with Single or Multiple Doses of a Natural Porcine Surfactant 26

Skov, L.; Bell, A.; Greisen, G. $\quad$ Surfactant Administration and the Cerebral Circulation Haumont, D.; Rössle, C; Clercx, A.; Spehl, M.; Biver, A. Richelle, M.; Carpentier, Y.A. Modifications of Surfactant Phospholipid Pattern in Premature Infants Treated with Curosurf: Clinical and Dietary Correlations

37

Svenningsen, N.W.; Björklund, L.; Vilstrup, C; Werner, O.

Lung Mechanics (FRC and Static Pressure-Volume Diagram) after Endotracheal Surfactant Instillation: Preliminary Observations

44

Walti, H.; Boulé, M.; Moriette, G. Relier, J.P.

Pulmonary Functional Outcome at One Year of Age in Infants Treated with Natural Porcine Surfactant at Birth

48

Tubman, T.R.J.; Rankin, S.J.; Halliday, H.L.; Johnston, S.S.

Surfactant Replacement Therapy and the Prevalence of Acute Retinopathy of Prematurity 54

Egberts, J.

Estimated Costs of Different Treatments of the Respiratory Distress Syndrome in a Large Cohort of Preterm Infants of Less than 30 Weeks of Gestation

59 
Author Index

66

Subject Index

66

VI

Contents 